\title{
Research on Teaching and Organization Change in the Perspective of Creative Talents Cultivation
}

\author{
Yushu Shi \\ Handan Polytechnic College \\ Department of Literature and Law \\ Handan, China \\ hbhdsys@sina.cn
}

\author{
Yuhai Li \\ Hebei Vocational College of Labor Relations \\ Science and Engineering \\ Shijiazhuang,China \\ hbsjzlyh@sina.cn
}

\author{
Jingtang Jia \\ Handan Polytechnic College \\ Foundation Department \\ Handan, China \\ hbhdjjt@sina.cn
}

\begin{abstract}
College teaching and research organizations are university's fundamental part of the constituent elements, and they determine the strength and level of universities, show the body's health and vitality of universities and shoulder the task of cultivating innovative talents.After a long term of reform, China's colleges and universities teaching and research organizations have achieved some success, but there are still many problems, which affected the cultivation of innovative talents. In order to improve teaching quality and cultivate innovative talents, we propose some main approachesto implementation change of university teaching and research organization.
\end{abstract}

Keywords-creative talents; college teaching; changeof research organization

\section{INTRODUCTION}

As science and economic development, thecommunity demands for talentsincreaseday by day, so the universitiesare important places for personnel training. Teaching and research organizations are the core organizations and motivation organizationsof universities, whose function directly determines the quality of the training and universities level.Therefore, college teaching and research organizations are faced with the real challenge of cultivating innovative talents effectively.China's current college teaching and types of research organization remain too old; management is not ideal; organize academic power shifts, the spirit of organizational teamwork and innovation is inadequate, and these various states impede innovation and personnel training. Therefore,achieving teaching and change and transformation of research organization become urgent tasks and important issue of innovative training objectives.

\section{ISSUES OF INNOVATIVE TRAINING ON CURRENT}

COLLEGE TEACHING AND RESEARCH ORGANIZATIONS

\section{A. Types of Organization Remained Too Old}

By contrast to the era of domination of teaching and research room, China's university teaching and research organization, structure, pattern and so on are more various, however, old problems of organizational type still exist, andit cannot fully meet the needs of innovation and personnel training. In our colleges and universities, many institutesbased on postgraduate education and research and researchcentersare single discipline organizations with few personnel, small scale and a single teaching and research staff knowledge background. The vast majority of college teaching research organizations has formal organizational forms and stable staffing,few semi-organized and dynamic organizations. Thus, the fixed rigid personnel management, the lack of ability to respond to the surroundings and self-survival and development energy and other issues in our university teaching and research organizationsare not only widespread, but also more serious. Most teaching and research organizations have low degree of internationalization.

\section{B. UnsatisfactoryOrganization and Management Model}

For the same type of college, the effective internal management model should have the same characteristics.Namely grassroots organizations of teaching and research under ideal conditions and should have a unique relationship model with colleges and schools ${ }^{[1]}$. The fact that the presence of two management modes and three management modes existin Chinese universities show awareness of the problem has not been uniform. In practice, colleges of the implementation of two management modes expand powers and continue to expand the institutes' autonomy in order to achieve flat management, but compared with the grass-roots organizations, colleges and 
administrative powers are too much government interference. Universities implementingthe three management mode,exist problemssuch as too much power of administrative functions, dividing too small and light weight management services and so on. No matter what modes, they are not in full compliance with the requirements of colleges and universities.

\section{Power Shift of Organizational Academic}

Offside of systems, regulations and executive proven by all is the root cause of difficultly demonstrating academic power, which restricts organizations to cultivate innovative talents. But these acknowledged fact madeus lose sight of academic power for their reasons. In fact, the academic power shift itself also contributing to teaching and research organizations and even universities are causes of academic power not free publicity underlying. This offset phenomenon, not only will become an obstacle organization unassuming academic power, but also will weaken the organizational innovation atmosphere even will be difficult to cultivate innovative talents ${ }^{[2]}$. Teaching and research organizations, under the internal and external pressure, have to focus on teaching and research activities of the underlying economic interests. Interest-driven leads to economic characteristics enhanced of academic activities, makes interest-based academic power struggle is more obvious, and gradually evolves into a power struggle within the organization scholars.

\section{A lack of Innovation Organization Team and More}

With advances in science and technology, currently, to achieve major scientific and technological innovation, relying only on personal power has been unrealistic.Teaching team-workers among researchers increasingly become an indispensable prerequisite foundation.In thisbackground,despite the long-standing university teachers have been given due understanding and respect about highly individualized academic work, and in most cases, is still encouraging teachers to independent innovation. However, in some areas of current technology, it is difficult to achieve major academic breakthrough without teamwork.In recent years, too much emphasis on the introduction of competition in college teacher evaluation and incentive, greatly stimulated the enthusiasmof research staff for teaching, ignoring the important role of teamwork, and even the narrow interests of insurance concept.Besides, lacking of innovation in teaching and research organization is currently relatively common problem in the universities.

\section{THE MAIN WAYS OF ORGANIZATIONAL CHANGE}

\section{ABOUT UNIVERSITYTEACHING AND RESEARCH ON}

\section{INNOVATIVE TRAINING}

\section{A. ClearingValue Orientation About Teaching and}

\section{Research Organizations}

Firstly,take fostering innovation and talent as a fundamental goal. The fundamental goal of teaching and research organizations is to cultivate talents, to teach and research, to ideologically educate, to train teachers and so on, all these should be subordinated to the primary task and associated with it. Students through participation in research, which can be purposefully active learning theoretical knowledge required for positive thinking.In practice, they should develop the ability of all aspects and creative spirit. It also can develop students' rigorous scholarship, pragmatic style of work and team spirit of collaboration; and be betterable to promote the exchange of information between teachers and teaching and learning. Therefore, colleges should handle the relationship between teaching and research with the fundamental goal of helping foster innovation and talents.Secondly, take create scientific and technological achievements as the main task. Tasks of teaching and research organizations for scientific research will increasingly be important with the development of the times, and even become an important powerof knowledge innovation, promoting scientific and technological achievements into practical productive forces.Besides, the school-run high-tech industry should be developed to coordinatethe research and industrial development in order to take the road of combining production and research. However, the requirements for scientific research should be from the organization's mission and the actual conditions of departure. In particular, doing a good job teaching should pay a lot of labor, and its benefits are intangible and difficult to measure specific.

\section{B. Teaching and Research Organizations' Operating Mode}

Power configuration is the unavoidable reality ofteaching and research organization change, which determines the organization of teaching and research administrative power and academic power combinations. Knowledge management reformed and operation mode of team would be better suited to the current teaching and research organizations. Knowledge Managementthroughthe systematic use ofinformation contentcan effectivelymake a variety ofknowledgesharing. Using the collective wisdom can improve organizational adaptability, creativity and academic efficiency of the activities. With the development of science and technology, organizing teaching and research activities on the collective wisdom grows strong, so the mode of operation will be an effective team of university teaching and research organization operating mode. A higher degree of interdependence of team members exists, such as complementary professional knowledge and skills, using a common method of teaching and research and mutual responsibility.

\section{Strengthen Internal Governance of Teaching and \\ Research Organizations}

Firstly,improve the organization of teaching and research incentives.Interdisciplinary teaching and personnel incentives of research university organizations encourage colleges and universities teaching and research personnel to involve in research activities and joinresearch organizations.Secondly, establish the organization of teaching and research personnel selection and elimination mechanism. Colleges with complicated personnelof teaching and research require a certain administrative support staff to deal with academic matters relating toor independent of the administrative affairs. Therefore, the establishment of a flexible selection system will help improve youth's academic teaching and research staff enthusiasm. Thirdly,improve the university's academic teaching and research organization evaluation mechanism. Discipline Evaluation of Teaching and Research relates to the direction of organizational development and involves in organizing various aspects of the work. To avoid 
monopolies and individual academic seniority and other undesirable phenomena, innovative science academic evaluation methods should be innovatedfor the more flexible and effectiveevaluation mechanism ${ }^{[3]}$.

\section{Optimizing the External Environment ofTeaching and \\ Research Organizations}

Firstly,encourage academic autonomy of teaching and research organization. Academic autonomy of teaching and research organizations is very important to cultivate innovative talents. Academic autonomy promotes innovation personnel training and development of teachers and students to adapt to the challenges of academic life and social capabilities.Then, actively expand the teaching and research organizations with outside support. Both the society and market should cooperate and develop mutually withresearch organizations and university teaching.Increase social contacts of issue and focus and promote scientific and technological research innovation to spread academic spiritual and cultural development of society and influence of radiation. The last but not the least,form culture atmosphere of collaborative innovationofteaching and research in organizational. Currently, the economic and social transformationupgrading constantly, college teaching and research organizations need to change in order to protect themselves and the sustainable development of the entire higher education. The establishment of depth cooperation between research institutes and teaching and social research organizationssolved the current prevalence of teaching and research and the national economic construction disjointed, and personnel training disjointed urgent problem. University, as a key control, it is necessary to obtain efficient allocation of resources to provide strategic support for the development of the colleges and research organizations.

\section{CONCLUSION}

With the transformation of social, political, economic and cultural environment, the society demands for talents continues to increase. Demands for talents ofhigher educationscience and research organizations to adapt to economic and society must be constantly reformed.This paper is from the inherent logic of innovative training, clearly analyzing the innovation and the role of human resources of teaching and research organizations of different types at different times. Eventually, order to understand the current university teaching and research organizations with innovative training was found unsuited to the purpose. We proposed main ways of organizational change based on cultivating innovative talents of university teaching and researchorganizations.

\section{REFERENCES}

[1] Zheng Xiaoqi and Wang Zhanrui,The Reform and development of research university academic organizations [M]. Beijing: Tsinghua University Press, 2009:174.

[2] Chen Ruosong,Integration and cultivation of InnovativeAbility [M]. Wuhan: Huazhong Normal University Press, 2003:15.

[3] Yao Qihe, Higher Education Management [M]. Wuhan: Huazhong University Press, 2000: 149. 